\title{
Perinatal and Socio-Economic Risk Factors of Autism in Children attending a Tertiary Care Hospital in Bangladesh
}

Fatema Ferdousy SM${ }^{1}$, Md Mizanur Rahman², Shaheen Akhter ${ }^{3}$, Kanij Fatema ${ }^{4 *}$ and Muzharul Mannan ${ }^{5}$

${ }^{1}$ Psychologist, Department of Pediatric Neurology, Bangabandhu Sheikh Mujib Medical University, Bangladesh

${ }^{2}$ Chairman and Professor, Department of Pediatric Neurology, Bangabandhu Sheikh Mujib Medical University, Bangladesh

${ }^{3}$ Project Director and Professor, Institute of Pediatric Neurodisorder and Autism, Bangabandhu Sheikh Mujib Medical University, Bangladesh

${ }^{4}$ Associate Professor, Department of Pediatric Neurology, Bangabandhu Sheikh Mujib Medical University, Bangladesh

${ }^{5}$ Training Coordinator, Institute of Pediatric Neurodisorder and Autism, Bangabandhu Sheikh Mujib Medical University, Bangladesh

Submission: December 10, 2018; Published: January 17, 2019

*Corresponding author: Kanij Fatema, Associate Professor, Department of Pediatric Neurology, Bangabandhu Sheikh Mujib Medical University, Bangladesh

Abstract

Objective: Autism is a neurodevelopmental disorder where genetic factors play causal role. This case-control study explored the association between perinatal and socioeconomic status with risk of autism.

Method: It was a case control study among children who came from different areas of the country during the period of 2005 to 2015 for assessment in the outdoor facility of Bangabandhu Sheikh Mujib Medical University. One hundred children were diagnosed autism by Autism Diagnostic Observation Schedule (ADOS)-Generic. Among them 79 were boys and 21 were girls. Another one hundred children without autism were taken as control, 65 of them were boys and 35 were girls. Perinatal and socioeconomic risk factors were analyzed in these two groups, using medical records.

Result: Mean age of the ASD children was 3.51+1.58 year and control was $3.80+1.53$. Male predominance was observed in ASD children. After univariate analysis three significant variables identified to pose as risk for autism. These were parental advanced level of education $(\mathrm{P}=<0.001)$, urban residence $(\mathrm{P}=<0.001)$ and neonatal jaundice $(\mathrm{P}=<0.001)$. Variables like male sex, occupation as service holder and low birth weight at birth approached significance at the 0.05 level.

Conclusion: Results suggested that parental profile as well as perinatal environment are associated with risk of autism and this factor act independently.

Keywords: Autism; Perinatal; Socioeconomic; Risk factor

Abbreviations: ASD: Autism Spectrum Disorders; ADOS: Autism Diagnostic Observation Schedule; IPNA: Institute of Paediatric Neurodisorder and Autism; BSMMU: Bangabandhu Sheikh Mujib Medical University; BIND: Bilirubin-Induced Neurologic Dysfunction

\section{Introduction}

Autism spectrum disorders (ASD) are characterized by impaired social interactions, communication deviance and restricted stereotypical behavioral pattern. The prevalence of ASD ranges from 13.1 to 29.3 per 1,000 children aged 8 years in different communities throughout the United States [1] whereas prevalence in Bangladesh in rural community was found $0.75 / 1000$ children. The study was done by screening tool MCHAT [2]. ASD is typically lifelong neuro-developmental disorder with onset before the age of 3 years $[3,4]$. The etiology of ASD is not fully understood, but twin and family studies suggest that genetic factors play substantial causal role. The recurrence risk of autistic probands is 2 to $5 \%$ [5,6]. While genetic disorders are commonly comorbid with autism, no genetic disorder is uniformly associated with autism. Similar cases of autism occur in children with and without genetic disorders. Given the variability in autism, even in groups of children who have the same genetic disorders, it seems likely that environmental factors play an important role in the development of these disorders and may influence severity $[7,8]$.

It has been hypothesized that prenatal, natal and postnatal complications as well as social status of the parents may act through independent etiologic pathways to increase the risk of autism or may interact with a genetic deposition to increase the risk by interfering at critical times in the developmental process. 
Several studies have focused on perinatal and socio-economic risk factors for autism. However, many of these studies have been done in small sample size. Even in some studies proper diagnostic tool has not been implemented. Further very few studies have taken place in developing country where the social burden is more. A number of studies examined several risk factors without mentioning the statistical significance $[7,9,10]$. Thus there is minimal consistent pattern of perinatal and social risk factors associated with autism. These variable results may be due to difference in the socioeconomic status, variation in the diagnostic criteria, health care facility and different types of control group along with the diagnostic tool variability. Other problems involved are differing study methodology and variability of the information source $[11,12]$.

On the above background, this study has been done in a developing country like Bangladesh to analyze the risk factors of autism. The strength of the study is that we used Autism Diagnostic Observation Schedule (ADOS) -Generic for diagnosis of autism and we had a control group to make the study reliable.

\section{Method and Material}

\section{Study setting}

This study was carried out in the Institute of Paediatric Neurodisorder and Autism (IPNA), Bangabandhu Sheikh Mujib Medical University (BSMMU), Dhaka, a tertiary level teaching facility and Medical University in capital of Bangladesh.

\section{Inclusion Criteria}

a. Children of 2- 6 year

b. Diagnosed as autism by Autism Diagnostic Observation Schedule (ADOS) -Generic by a certified psychologist.

\section{Exclusion Criteria}

Who already diagnosed as other neurodevelopmental disorder or psychiatric disorder.

\section{Study Design}

It was a case control study; cases were taken as per inclusion criteria ranging from 2-16 years. 100 children met the inclusion criteria as Autism Spectrum Disorder (ASD). The control sample was comprised of 100 children in the same age group. The study was done from March 2005 to September 2015. Patient records

\section{Parental Characteristics}

Table 2: Distribution of the children by parent's information.

\begin{tabular}{|c|c|c|c|}
\hline Parent's information & $\begin{array}{c}\text { Autism Group } \\
(\mathbf{n = 1 0 0 )} \\
\text { No. (\%) }\end{array}$ & $\begin{array}{c}\text { Control Group } \\
\text { (n=100) } \\
\text { No. (\%) }\end{array}$ & P value \\
\hline Father & & & 0.102 \\
\hline Age & 29 & 40 & \\
\hline$<35$ years & 71 & 60 & $<0.001^{*}$ \\
\hline Education & & & \\
\hline
\end{tabular}

were reviewed and data was collected on structured proforma especially prepared for this purpose. The controls were recruited randomly on consecutive days matching their age 2-16 years and having no features of autism. Detailed history regarding age, sex, environment, parental educational, social status, and habitat was taken. Antenatal history was taken including age of parent at birth, history of threatened abortion, any fetal loss, parity, chronic illness like hypertension, diabetes, infection in pregnancy, medication during pregnancy. Natal and postnatal history including gestational age, perinatal insult like asphyxia, prematurity, sepsis, birth weight, mode of birth etc. was taken. Developmental history, family history and vaccination history was taken.

\section{Data Management and Statistical Analysis}

The data was coded, entered and analyzed using Windows SPSS version 21.0. In descriptive analysis, the mean and standard deviations of the continuous variables and percentages of categorical variables were computed. A p-value of $<0.05$ was considered statistically significant.

\section{Ethical Considerations}

Ethical clearance was taken from the Ethical Review Committee (ERC) of the Bangabandhu Sheikh Mujib Medical University (BSMMU), Dhaka.

\section{Results}

\section{Baseline Characteristics}

Table 1: Age and sex of the studied children.

\begin{tabular}{|c|c|c|c|}
\hline & $\begin{array}{c}\text { Autism Group } \\
(\mathbf{n = 1 0 0 )} \\
\text { Mean } \pm \text { SD }\end{array}$ & $\begin{array}{c}\text { Control Group } \\
(\mathbf{n = 1 0 0 )} \\
\text { Mean } \pm \text { SD }\end{array}$ & P value \\
\hline Age & $3.51 \pm 1.58$ & $3.80 \pm 1.53$ & 0.752 \\
\hline Male & 79 & 65 & $0.027^{*}$ \\
\hline Female & 21 & 35 & \\
\hline
\end{tabular}

No significant difference of age was seen between children with Autism and Control group in respect of age $(p=0.752)$ but male predominance was found in ASD group ( $p=0.027)$.

The age and sex of our children are presented in Table 1. Mean age of children with autism was $3.51+1.58$ year and control was $3.80+1.53$. The majority of the children with autism (79\%) were male which was statistically significant comparing the from control group. 


\section{Global Journal of Intellectual \& Developmental Disabilities}

\begin{tabular}{|c|c|c|c|}
\hline $\begin{array}{c}\text { Illiterate } \\
<\text { Graduate } \\
\text { Graduate } \\
>\text { Graduate }\end{array}$ & $\begin{array}{c}0 \\
28 \\
28 \\
44\end{array}$ & $\begin{array}{c}2 \\
57 \\
14 \\
27\end{array}$ & \\
\hline Occupation & & & $0.007^{*}$ \\
\hline $\begin{array}{c}\text { Service } \\
\text { Business } \\
\text { Unemployed } \\
\text { Others }\end{array}$ & $\begin{array}{c}66 \\
27 \\
2 \\
5\end{array}$ & $\begin{array}{c}51 \\
25 \\
3 \\
21\end{array}$ & \\
\hline Income & & & 0.985 \\
\hline $\begin{array}{c}<10000 \\
10000-30000 \\
>30000\end{array}$ & $\begin{array}{l}19 \\
59 \\
22\end{array}$ & $\begin{array}{l}19 \\
58 \\
23\end{array}$ & \\
\hline \multicolumn{4}{|l|}{ Mother } \\
\hline Age & & & 0.212 \\
\hline $\begin{array}{l}<35 \text { years } \\
>35 \text { years }\end{array}$ & $\begin{array}{l}77 \\
23\end{array}$ & $\begin{array}{l}84 \\
16\end{array}$ & \\
\hline $\begin{array}{l}\text { Education } \\
\text { Illiterate } \\
<\text { Graduate } \\
\text { Graduate } \\
>\text { Graduate }\end{array}$ & $\begin{array}{c}3 \\
41 \\
27 \\
29 \\
\end{array}$ & $\begin{array}{c}1 \\
75 \\
7 \\
17 \\
\end{array}$ & $<0.001 *$ \\
\hline Occupation & & & $0.032^{*}$ \\
\hline $\begin{array}{c}\text { Service } \\
\text { Business } \\
\text { Housewife } \\
\text { Others }\end{array}$ & $\begin{array}{c}34 \\
4 \\
62 \\
0\end{array}$ & $\begin{array}{c}24 \\
0 \\
74 \\
2\end{array}$ & \\
\hline Income & & & 0.052 \\
\hline $\begin{array}{c}<10000 \\
10000-30000 \\
>30000\end{array}$ & $\begin{array}{c}83 \\
14 \\
3\end{array}$ & $\begin{array}{c}93 \\
7 \\
0\end{array}$ & \\
\hline Resident & & & $<0.001 *$ \\
\hline $\begin{array}{l}\text { Rural } \\
\text { Urban }\end{array}$ & $\begin{array}{l}18 \\
82\end{array}$ & $\begin{array}{l}45 \\
55\end{array}$ & \\
\hline Consanguinity & & & 0.205 \\
\hline $\begin{array}{l}\text { Yes } \\
\text { No }\end{array}$ & $\begin{array}{c}6 \\
94\end{array}$ & $\begin{array}{l}11 \\
89\end{array}$ & \\
\hline Any behavioral problem in father & 0 & 0 & - \\
\hline $\begin{array}{l}\text { Yes } \\
\text { No }\end{array}$ & 100 & 100 & \\
\hline Any behavioral problem in other & 1 & 0 & 0.316 \\
\hline $\begin{array}{l}\text { Yes } \\
\text { No }\end{array}$ & 99 & 100 & \\
\hline
\end{tabular}

Table 3: It demonstrates the binary logistic regression analysis of Odds Ratios for characteristics of the children likely to develop ASD. The variables revealed to be significantly associated with ASD in multivariate analyses were all entered directly into the model. Of the variables, higher education, urban area and neonatal jaundice were emerged as independent predictors of ASD $(p=0.01, p=0.01$ and $p<0.001$ respectively).

\begin{tabular}{|c|c|c|c|c|c|c|c|}
\hline & \multirow{2}{*}{} & B & S.E. & df & \multirow{2}{*}{ P value } & \multirow{2}{*}{ OR } & \multicolumn{2}{|c|}{ 95\% C.I.for EXP(B) } \\
\cline { 3 - 8 } & & & & & & Lower & Upper \\
\hline Education & 1.21 & 0.48 & 1.00 & 0.01 & 3.34 & 1.30 & 8.63 \\
\hline Occupation & -0.66 & 0.68 & 1.00 & 0.33 & 0.52 & 0.14 & 1.95 \\
\hline Income & -1.06 & 0.60 & 1.00 & 0.08 & 0.35 & 0.11 & 1.13 \\
\hline Urban & 1.00 & 0.40 & 1.00 & 0.01 & 2.72 & 1.24 & 5.97 \\
\hline Consanguinity & 1.17 & 0.83 & 1.00 & 0.16 & 3.21 & 0.64 & 16.21 \\
\hline Diabetes mellitus & -19.52 & 24003.50 & 1.00 & 1.00 & 0.00 & 0.00 & - \\
\hline
\end{tabular}




\section{Global Journal of Intellectual \& Developmental Disabilities}

\begin{tabular}{|c|c|c|c|c|c|c|c|}
\hline Hypertension & -0.83 & 0.67 & 1.00 & 0.22 & 0.44 & 0.12 & 1.62 \\
\hline Maternal stress during pregnancy & -21.11 & 22506.10 & 1.00 & 1.00 & 0.00 & 0.00 & - \\
\hline Neonatal jaundice & -4.09 & 1.33 & 1.00 & $<0.001$ & 0.02 & 0.00 & 0.23 \\
\hline Neonatal seizure & -0.52 & 1.21 & 1.00 & 0.67 & 0.59 & 0.06 & 6.38 \\
\hline Delayed crying & 1.21 & 0.63 & 1.00 & 0.06 & 3.37 & 0.97 & 11.65 \\
\hline
\end{tabular}

Age of the parents and their income had no significant impact on autism. However, level of education seemed to have effect on autism. Parents of children with autism, both mother and father, who had done graduation and above had significantly increased autistic children ( $\mathrm{p}$ value significant, Table 2). Moreover, profession of the parents also showed significant impact on autism. In this study, mother and fathers who were service holder had more children with autism (P value 0.032 and

\section{Pregnancy and Delivery Complications}

Table 4: Low birth weight babies were significantly associated with autism. ( $p$ value $<0.001$ ).

\begin{tabular}{|c|c|c|c|}
\hline Natal problems & $\begin{array}{c}\text { Autism Group } \\
(n=100) \\
\text { No. }(\%)\end{array}$ & $\begin{array}{c}\text { Control Group } \\
(n=100) \\
\text { No. }(\%)\end{array}$ & $P$ value \\
\hline Gestational age & & & 0.081 \\
\hline Preterm Term & $\begin{array}{r}3 \\
97\end{array}$ & $\begin{array}{c}1 \\
99\end{array}$ & \\
\hline Mode of delivery & & & 0.113 \\
\hline $\begin{array}{c}\text { LUCS } \\
\text { NVD }\end{array}$ & $\begin{array}{l}65 \\
35\end{array}$ & $\begin{array}{l}54 \\
46\end{array}$ & \\
\hline Birth weight & & & $<0.001^{*}$ \\
\hline $\begin{array}{c}\text { Normal } \\
\text { LBW } \\
\text { VLBW }\end{array}$ & $\begin{array}{c}75 \\
21 \\
4\end{array}$ & $\begin{array}{c}87 \\
12 \\
1\end{array}$ & \\
\hline Prolong labour & & & 0.155 \\
\hline $\begin{array}{l}\text { Yes } \\
\text { No }\end{array}$ & $\begin{array}{c}0 \\
100\end{array}$ & $\begin{array}{c}2 \\
98\end{array}$ & \\
\hline Any other problem during delivery & & & 0.155 \\
\hline $\begin{array}{l}\text { Yes } \\
\text { No }\end{array}$ & $\begin{array}{c}2 \\
98\end{array}$ & $\begin{array}{c}0 \\
100\end{array}$ & \\
\hline
\end{tabular}

Among maternal pregnancy complications threaten abortion, pre-eclamptic toxemia, diabetes mellitus, cardiac disorder, hypertension, environmental stress, maternal stress, multiple pregnancy did not occur significantly higher rate than those of normal. Among the perinatal factors, significant higher incidence of low birth weight and very low birth weight babies were found in autistic group ( $\mathrm{p}$ value $<0.001$ ). While, gestational age, mode of delivery, prolong labour were not significantly associated with either of the groups. In the postnatal complications neonatal jaundice was present in higher number in autistic group while perinatal asphyxia was more common in control group. No significant relation with neonatal seizure was found. (Tables 4 \& 5). After univariable logistic regression neonatal jaundice emerged as independent predictor of ASD $(\mathrm{p}<0.001)$.

\section{Discussion}

This is a case control study nested in children of 2-16 year in a tertiary care centre to address the possible association of
007 respectively). Moreover, place of habitat also had significant relation with autism; urban children had more frequency of autism than rural (P value <0.001). However, in multivariate analysis higher education, residing in an urban area emerged as independent predictor for ASD (P value 0.01, 0.01, OR 3.34, 2.72 respectively) (Table 3 ). Behavioral problems in parents and consanguinity did not seem to pose any risk in autism. perinatal and socio-economic risk factors in developing autism. The sample size allows reliable estimates of risk factors in univariate analyses. We have done ADOS for autism diagnosis which is generally considered having high validity and reliability [13]. We studied children attending outdoor facility of the hospital.

The study suggests role of perinatal and social risk factors in ASD population. After analyzing univariate analysis three significant variables were identified which were parental graduate level of education, urban residence and neonatal jaundice. Variables like male sex, occupation as service holder and low birth weight at birth approached significance at the 0.05 level

We found a significant link between autism and neonatal jaundice. Similar association has been found by Luis E Lozada et al in their study [14]. They found that children who develops ASD are more likely to have an admission with a diagnosis of 


\section{Global Journal of Intellectual \& Developmental Disabilities}

jaundice in the neonatal period (odds ratio $=1.18 ; \mathrm{P}=.001$ ) and more likely to require treatment for this jaundice (odds ratio $=$ 1.33; $\mathrm{P}=.008)$. We did not studied the requirement of treatment of jaundice as variable. It is already known that bilirubin is a neurotoxin. The globus pallidus, cerebellum, hippocampus, and subthalamic nuclear bodies have been identified as areas in the brain vulnerable to bilirubin toxicity $[15,16]$. There is evidence of lower gray matter volumes in the putamen and cerebellar hypoplasia in individuals with autism, creating a degree of overlap that may indicate shared mechanisms [17-19]. Additionally, there is overlap in the clinical features of bilirubininduced neurologic dysfunction (BIND) and ASD [15] (Table 6).

Table 5: In the post-natal condition of the study children, neonatal jaundice was significantly associated with children with autism $(p<0.05)$ and delayed cry with control group ( p 0.038).

\begin{tabular}{|c|c|c|c|}
\hline Post-natal condition & Autism Group (n=100) No. (\%) & Control Group $(n=100)$ No. $(\%)$ & $P$ value \\
\hline Neonatal jaundice & & & $<0.001^{*}$ \\
\hline Yes & 19 & 1 & \\
\hline No & 81 & 99 & \\
\hline Neonatal seizure & & & 0.651 \\
\hline Yes & 2 & 3 & \\
\hline No & 98 & 97 & \\
\hline Delayed crying & & & $0.038^{*}$ \\
\hline Yes & 6 & 15 & \\
\hline No & 94 & 85 & \\
\hline Any other problem during postnatal period & & & 0.174 \\
\hline Yes & 4 & 1 & \\
\hline No & 96 & 99 & \\
\hline
\end{tabular}

Table 6: None of the prenatal factors could be associated with increased number of autism.

\begin{tabular}{|c|c|c|c|}
\hline Prenatal condition & Autism Group $(n=100)$ No. $(\%)$ & Control Group $(n=100)$ No. $(\%)$ & $P$ value \\
\hline Threaten abortion & & & 0.756 \\
\hline Yes & 5 & 6 & \\
\hline No & 95 & 94 & \\
\hline Pre Eclamtic Toxaemia & & & 0.316 \\
\hline Yes & 0 & 1 & \\
\hline No & 100 & 99 & \\
\hline Diabetes Mellitus & & & 0.155 \\
\hline Yes & 2 & 0 & \\
\hline No & 98 & 100 & \\
\hline Cardiac cause & & & - \\
\hline Yes & 0 & 0 & \\
\hline No & 100 & 100 & \\
\hline Hypertension & & & 0.138 \\
\hline Yes & 12 & 6 & \\
\hline No & 88 & 94 & \\
\hline Maternal stress during pregnancy & & & 0.081 \\
\hline Yes & 3 & 0 & \\
\hline No & 97 & 100 & \\
\hline Multiple pregnancy & & & 0.651 \\
\hline Yes & 2 & 3 & \\
\hline No & 98 & 97 & \\
\hline Any other problem during prenatal period & & & 0.017 \\
\hline Yes & 2 & 10 & \\
\hline No & 98 & 90 & \\
\hline
\end{tabular}

Birth weight has long been studied as a risk factor for birth weight was significantly associated with ASD. Other factors developing autism. Our study result had similarity with study done by Burd et al. [7] and Larsson $\mathrm{HJ}$ et al. [8] who found low found to be significant were Apgar score at one and five minutes, father's age, the trimester prenatal care started, termination 
of prior pregnancy, gestation less than 36 weeks $[7,8]$. This factors were not analyzed in our study. It is noteworthy that birth weight is the net result of at least 3 factors: genetic, growth potential, duration of pregnancy and rate of fetal growth. The genetic growth potential is unknown, making it difficult to disentangle the effect of these factors [20]. Birth weight also found to be important risk factor in autism in a large, register based study from Sweden [21]. It is here to mention that birth weight, birth length, pattern of intrauterine growth, mode of delivery, complications during pregnancy have frequently been studied in link with autism. Hultman et al. in their study found three fold increases in risk of autism among children with a low 5 minute Apgar score [21]. Congenital malformation is also well documented in autism which is not studied in our work [6].

Apart from the fetal factors, we also studied parental behavior. Parental behavioral disorder did not seem to be associated with autism in our study but some studies done in abroad found strong association between them [8]. Historically genetic links have been found between schizoid personality traits and autism [22]. In some studies advanced parental age and maternal age were significantly related to autism [2325]. However, our results showed no increased risk of autism associated with parental age.

We studied the information about the socioeconomic status of the parents. In unadjusted analyses urban population and graduate level of education emerged as independent predictor of autism. Burd L et al. in their case control study in USA have also found that maternal education was significantly associated with autism but in a reverse way. For each year of difference in parents education between the cases and controls (lower education was the risk factor for autism), the risk of autism increased. After logistic regression the odds ratio was 1.24 [7]. On the other hand, Larsson et al did not find any statistically significant association between autism and maternal education, rather they have mentioned that socioeconomic factors play little or no role in the etiology of their country Denmark where access to health care system is equally available for all and free of charge [8]. In a very recent study by For-Wey Lung, although more children of mothers with lower-than-average education were positive on screening, more children of mothers with higher-than-average education were also diagnosed with ASD. Thus here, maternal educational disparity was found between ASD clinical diagnosis and community screening [26].

In our study we did not find any significance of occupation and income of parents after logistic regression. But in some studies, association of occupation has been related to autism. Aisha et al. have found that certain paternal occupations, including engineering, healthcare, and accounting/financial analysis are in a higher likelihood of having a child with an ASD diagnosis. Furthermore, they have observed more severe autistic symptomology (as indicated with higher ADI-R scores) in children of parents who both had highly technical occupations as well as in those for whom only the father had a highly technical occupation [27].

Geographic variation in ASD occurrence has been observed, and urban residence has been suggested to serve as a proxy for etiologic and identification factors in ASD. We examined the association between urbanicity level and ASD. After logistic regression children who belonged to urban areas had a significantly increased diagnosis of autism. The urban-rural geographic gradient has also been detected for other psychiatric disorders than ASD, e.g. schizophrenia, bipolar affective disorder, and depression [28-30]. The high risk found in our study for children born in the capital and capital suburb could support the hypothesis of environmental agents acting during pregnancy or early in life of the child affecting the risk for ASD, such as infections or air pollutants containing neurotoxic or immunotoxin properties, a hypothesis that has been investigated by Kalkbrenner et al. [31] To date, however, there is little evidence for the influence of such environmental pollutants including specific agents on the development of ASD. Our finding of an increased risk of ASD in urban areas compared to rural areas is in accordance with findings from studies of geographically and ethnically diverse areas such as Japan, Taiwan and the United States [32-34].

We studied the association of perinatal factors like threaten abortion, pre-eclamptic toxemia, diabetes mellitus, cardiac disorder, hypertension, environmental stress, maternal stress, multiple pregnancy, mode of delivery, gestational age, prolong labour causing autism. None of these seemed significantly related to autism. But some studies have found perinatal factors like breech presentation, primary caesarian section to be significantly causing autism $(\mathrm{P}<0.05)$ [35]. This relationship is difficult to explain. The over presentation of first-born children in ASD may be explained by the parents' reluctance to have more children after 1 child has been diagnosed with autism [36]. It is here to mention that currently the field of ASD genetics is expanding rapidly, and it is likely that genetic subsets will be identified in the near future [35]. However, the risk factors which we have identified may provide clue to an etiology of autism in developing country perspective like Bangladesh.

\section{Conclusion}

The finding of this study suggests that parental educational status, urban localization and neonatal jaundice are independently associated with ASD risk. So while reviewing a case of autism these factors should be taken into consideration. Moreover, additional investigations should be targeted to find out the environmental and genetic impact on autism. The strength of this study is that ADOS has been used by a pediatric psychologist to detect autism.

\section{Ethical Consideration}

Informed written consent has been taken from the parent/ legal guardian of the patients. Ethical clearance has been taken 
from the institutional review board of the university.

\section{Conflict of Interest}

No funding has been taken in this research work.

\section{References}

1. Baio J, Wiggins L, Christensen DL, Maenner MJ, Daniels J, et al. (2018) MMWR Surveill Summ 6(7): 1-28.

2. Akhter S, Hussain AHME, Shefa J, Kundu GK, Biswas A (2018) Prevalence of Autism Spectrum Disorder (ASD) among the children aged 18-36 months in a rural community of Bangladesh: A cross sectional study. F1000Res 7: 424.

3. Volkmar F, Chawarska K, Klin A (2005) Autism in infancy and early childhood. Annu Rev Psychol 56: 315-336.

4. Chew LC, King NM, O'Donnell D (2006) Autism: the aetiology, management and implications for treatment modalities from the dental perspective. Dent Update 33(2): 70-72, 74-76.

5. Bailey A, Le Couteur A, Gottesman I, Bolton P, Simonoff E, et al. (1995) Autism as a strongly genetic disorder: evidence from a British twin study. Psychol Med 25(1): 63-77.

6. Smalley SL, Asarnow RF, Spence A (1988) Autism and genetics: a decade of research. Arch Gen Psychiat 45: 953.

7. Burd L, Severud R, Kerbeshian J, Klug MG (1999) Prenatal and perinatal risk factors for autism. J Perinat Med 27(6): 441-450.

8. Larsson HJ, Eaton WW, Madsen KM, Madsen KM, Vestergaard M, et al (2005) Risk Factors for Autism: Perinatal Factors, Parental Psychiatric History, an Socioeconomic Status. Am J Epidemiol 161: 916-925.

9. Eaton WW, Mortensen PB, Thomsen PH, Frydenberg M (2001) Obstetric complications and risk for severe psychopathology in childhood. J Autism Dev Disord 31(3): 279-285.

10. Juul Dam N, Townsend J, Courchesne E (2001) Prenatal, perinatal, and neonatal factors in autism, pervasive developmental disorder-not otherwise specified, and the general population. Pediatrics 107(4): 63.

11. Deykin EY, MacMahon B (1980) Pregnancy, delivery, and neonatal complications among autistic children. Am J Dis Child 34(9): 860-864.

12. Lord C, Mulloy C, Wendelboe M, Schopler E (1991) Pre- and perinatal factors in high-functioning females and males with autism. J Autism Dev Disord 21(2): 197-209.

13. Bölte S, Poustka F (2004) Diagnostic Observation Scale for Autistic Disorders: initial results of reliability and validity. Z Kinder Jugendpsychiatr Psychother 32(1): 45-50.

14. Lozada LE, Nylund CM, Gorman GH, Hisle Gorman E, Erdie Lalena CR (2015) Association of Autism Spectrum Disorders With Neonatal Hyperbilirubinemia. Glob Pediatr Health 2: 1-5.

15. Bhutani VK, Johnson Hamerman L (2015) The clinical syndrome of bilirubin-induced neurologic dysfunction. Semin Fetal Neonatal Med 20: 6-13.

16. Bhutani VK, Wong R (2015) Bilirubin-induced neurologic dysfunction (BIND). Semin Fetal Neonatal Med 20: 1.

17. Bauman ML, Kemper TL (2005) Neuroanatomic observations of the brain in autism: a review and future directions. Int J Dev Neurosci 23:183-187.
18. Palmen SJMC, van Engeland H, Hof PR, Schmitz C (2004) Neuropathological findings in autism. Brain 127(12): 2572-2583.

19. Cheung C, Yu K, Fung G (2010) Autistic disorders and schizophrenia: related or remote? An anatomical likelihood estimation. PLoS One $5(8)$.

20. Wilcox AJ (2001) On the importance--and the unimportance-of birth weight. Int J Epidemiol 30(6): 1233-1241.

21. Hultman CM, Sparén P, Cnattingius S (2002) Perinatal risk factors for infantile autism. Epidemiology 13(4): 417-423.

22. Wolff S, Narayan S, Moyes B (1988) Personality characteristics of parents of autistic children: A controlled study. J Child Psychol Psychiatry Discipline 29(2): 143-153.

23. Croen LA, Grether JK, Selvin S (2002) Descriptive epidemiology of autism in a California population: who is at risk? J Autism Dev Disord 32(3): 217-224.

24. Glasson EJ, Bower C, Petterson B, de Klerk N, Chaney G, et al. (2004) Perinatal factors and the development of autism: a population study. Arch Gen Psychiatry 61(6): 618-627.

25. Croen LA, Najjar DV, Fireman B, Grether JK (2007) Maternal and Paternal Age and Risk of Autism Spectrum Disorders. Arch Pediatr Adolesc Med 161: 334-340.

26. Lung F, Chiang T, Lin S, Lee M, Shu B (2018) Advanced Maternal Age and Maternal Education Disparity in Children with Autism Spectrum Disorder. Matern Child Health J 22(7): 941-949.

27. Dickerson AS, Pearson DA, Loveland KA, Rahbar MH, Filipek PA (2014) Role of parental occupation in autism spectrum disorder diagnosis and severity. Res Autism Spectr Disord 8(9): 997-1007.

28. Sundquist K, Frank G, Sundquist J (2004) Urbanisation and incidence of psychosis and depression: Follow-up study of 4.4 million women and men in Sweden. Br J Psychiatry 184: 293-298.

29. Vassos E, Pedersen CB, Murray RM, Collier DA, Lewis CM (2012) Meta-analysis of the association of urbanicity with schizophrenia. Schizophr Bull 38: 1118-1123.

30. Pedersen CB, Mortensen PB (2006) Urbanicity during upbringing and bipolar affective disorders in Denmark. Bipolar Disord 8: 242-247.

31. Kalkbrenner AE, Daniels JL, Chen JC, Poole C, Emch M, et al. (2010) Perinatal exposure to hazardous air pollutants and autism spectrum disorders at age 8. Epidemiology 21: 631-641.

32. Hoshino Y, Kumashiro H, Yashima Y, Tachibana R, Watanabe M (1982) The epidemiological study of autism in Fukushima-ken. Folia Psychiatrica et Neurologica Japonica 36: 115-124.

33. Chen CY, Liu CY, Su WC, Huang SL, Lin KM (2008) Urbanicity-related variation in help-seeking and services utilization among preschool-age children with autism in Taiwan. J Autism Dev Disord 38: 489-497.

34. Rosenberg RE, Daniels AM, Law JK, Law PA, Kaufmann WE (2009) Trends in autism spectrum disorder diagnoses: 1994-2007. J Autism Dev Disord 39:1099-1111.

35. Bilder D, Pinborough Zimmerman J, Miller J, McMahon W (2009) Prenatal, perinatal, and neonatal factors associated with autism spectrum disorders. Pediatrics 123(5): 1293-1300.

36. Deykin EY, MacMahon B (1980) Pregnancy, delivery, and neonatal complications among autistic children. Am J Dis Child 134(9): 860-864. 
(C) This work is licensed under Creative

BY DOI: $10.19080 / G J I D D .2019 .06 .555677$

\section{Your next submission with Juniper Publishers} will reach you the below assets

- Quality Editorial service

- Swift Peer Review

- Reprints availability

- E-prints Service

- Manuscript Podcast for convenient understanding

- Global attainment for your research

- Manuscript accessibility in different formats

( Pdf, E-pub, Full Text, Audio)

- Unceasing customer service

Track the below URL for one-step submission https://juniperpublishers.com/online-submission.php 